\begin{tabular}{l|c|c}
\hline ISSN: 0001-5113 & ACTA ADRIAT., & REVIEW PAPER \\
AADRAY & $60(2): 115-126,2019$ & R \\
\hline \hline
\end{tabular}

\title{
Review of heterobranch molluscs fauna in the Boka Kotorska Bay, Montenegro
}

\author{
Milica JOVANOVIĆ ${ }^{*}$, Vesna MAČIĆ ${ }^{2}$, Domen TRKOV³, Martina ORLANDO- \\ BONACA $^{3}$ and Lovrenc LIPEJ ${ }^{3}$
}
${ }^{1}$ University of Montenegro, Faculty of Mathematics and Natural Sciences, G. Washington Street, 81000 Podgorica, Montenegro

${ }^{2}$ University of Montenegro, Institute of Marine Biology, P.O. Box 69, 85330 Kotor, Montenegro

${ }^{3}$ Marine Biology Station, National Institute of Biology, Fornače 41, Piran, SI-6330, Slovenia

Corresponding author,e-mail: milicaj@ucg.ac.me

Heterobranch molluscs fauna in Montenegro has been poorly investigated so far. The aim of the present paper is to improve the knowledge about species diversity of these marine organisms in the Boka Kotorska Bay, specific fjord-like entity in the southern Adriatic Sea. New records of seven heterobranch species were obtained by field surveys in 2017, while three new records were provided by analysing underwater photographs from previous periods. The resulted checklist summarizes the knowledge of the diversity of heterobranchs in the Boka Kotorska Bay from the oldest record in 1967 to the present day, and consists of a total of 62 heterobranch species.

Key words: heterobranch fauna, Boka Kotorska Bay, Montenegro

\section{INTRODUCTION}

Contrary to the northern and central Adriatic Sea the heterobranch fauna of Montenegrin and Albanian coastal waters has been poorly investigated so far (ZENETOS et al., 2016; LIPEJ et al., 2018). Among few studies, important information on molluscs in Montenegro were provided for the Boka Kotorska Bay by STJEPČEVIĆ (1967) and STJEPČEVIĆ \& PARENZAN (1980). Recently, ZENETOS et al. (2016) updated to 41 the number of heterobranch species recorded for Montenegro based on the observations carried out by SCUBA divers and underwater photographers. One year later, PETOVIĆ et al. (2017) published an annotated checklist of all molluscs from Montenegro. Among the whole 354 taxa of molluscs listed, 198 are gastropods 49 of which are heterobranchs. Four new heterobranch species were added to this list of species. (PETOVIĆ, 2018; MAČIĆ et al., 2018).

The aim of this work is to deepen the knowledge about the heterobranch fauna inhabiting the Boka Kotorska Bay. An exhaustive review of available published data, with new findings for species not previously reported and reports for new localities of already recorded species, is provided here for the Montenegrin coast. 


\section{MATERIAL AND METHODS}

\section{Study area}

The Montenegrin coast can be divided into two main parts, the Boka Kotorska Bay (BKB) and the open sea. The BKB, with a Mediterranean climate, is a specific fjord-like entity located in the southeastern Adriatic Sea. The bay is surrounded by Orjen and Lovćen mountains, and the coastline is $105 \mathrm{~km}$ long. The average depth is $27 \mathrm{~m}$, while the bottom is mainly muddy with few smaller rocky and sandy areas (LEPETIĆ, 1965). The most important characteristic of the bay is the specific habitat named »vrulja« - a freshwater spring under the sea surface. As a result of the freshwater input from numerous sources, temperature, salinity and currents in the $\mathrm{BKB}$ are significantly different from those commonly ascribed to the open sea (BELLAFIORE $e t$ al., 2011).

\section{Data collection and fieldwork}

Data about heterobranch species were collected on the base of different sampling methodologies, listed below:

1. Collection of previous data

(i) Analysis of published scientific and grey literature records

(ii) Analysis of underwater photographs (2011 - 2017)

2. Collection of new data by:

(i) Snorkeling

(ii) SCUBA diving

To prepare the present checklist, all published scientific and grey literature records of heterobranch in the study area were reviewed, as well as information available from the websites (previous www.seaslugforum.net and nowdays https://opistobranquis.info/en/guia). Moreover, additional data were collected from unpublished underwater photos taken during the previous seven years period (2011 - 2017). Collection of new data was done by snorkeling and SCUBA diving at 24 randomly chosen locations. The list

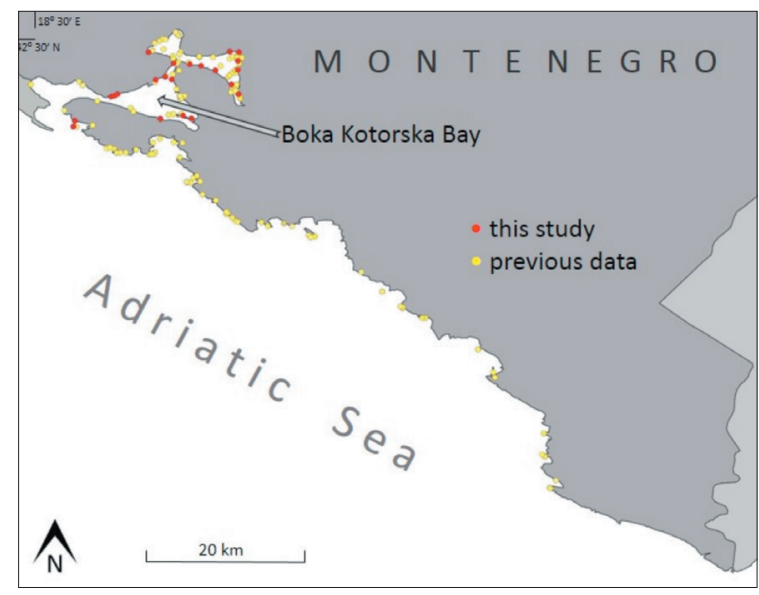

Fig.1. Distribution map of localities where heterobranch species were reported for the Montenegro and collected in the Boka Kotorska Bay (red circles are for this study, and yellow are for previous studies)

of all the sampling localities, highlighting both previous and our new heterobranchs findings are reported in Fig. 1.

Monographies published by TRAINITO \& DONNEDU (2014) and LIPEJ et al. (2018) and the web site www.seaslugforum.net, have been used as a reference to identify observed taxa. The taxonomy and nomenclature here adopted follow the World Register of Marine Species - WoRMS (www.marinespecies.org). For the family Flabellinidae we decided to follow the taxonomy proposed by FURFARO et al. (2018).

The habitat preferences of heterobranch species in the study area were surveyed using nondestructive visual census methods, conducted by snorkeling and SCUBA diving. Therefore, a number of environmental variables were recorded at locations where heterobranch species were found, at different scales. The term "macrohabitat" has been used to define extensive areas, characterized by comparable ecological features, such as seagrass meadow or rocky bottom, supporting a large and complex flora and fauna. "Microhabitat" refers to conditions and/or organisms in the immediate vicinity of heterobranchs, even a single algal (e.g. Cystoseira sp.) or animal (e.g. Petrosia sp.) species. In this study the following microhabitat variables were a priori selected, as suggested by COPP \& GARNER (1995) and examined, adapted from Larsonneur, 1977 (in UNEP, 1998): bottom substrate composition 
[pebbles $(10-2 \mathrm{~cm})$, sand $(2-0.05 \mathrm{~mm})$, mud $(<0.05 \mathrm{~mm})$ and detritus], and the abundance of physical structures like: macrophytes (Posidonia oceanica (L.) Delile, 1813, Cymodocea nodosa (Ucria) Ascherson, 1870, Zosteraceae Dumortier, Cystoseira C. Agardh, 1820, Sargassum C. Agardh, 1820, Ulva L., 1753, Acetabularia acetabulum (L.) P.C.Silva, 1952, Halimeda tuna (J.Ellis \& Solander) J.V.Lamouroux, 1816, Flabellia petiolata (Turra) Nizamuddin, 1987, calcified algae, and algal turf), sponges (Petrosia (Petrosia) ficiformis (Poiret, 1789), Aplysina Nardo, 1834, Axinella Schmidt, 1862 and Dysidea avara (Schmidt, 1862)), corals (Leptogorgia sarmentosa (Esper, 1789), Spirastella cunctatrix Schmidt, 1868, Cladocora caespitosa (Linnaeus, 1767) and Savalia savaglia (Bertoloni, 1819)), ascidians (Phallusia mamillata $(\mathrm{Cu}-$ vier, 1815)), hydrozoa and mussels. For every environmental variable, presence/absence were recorded, within each microhabitat.

\section{Statistical data analyses}

In order to test for interspecific differences in microhabitat use, data were subjected to canonical correspondence analysis (CCA) (TER BRAAK, 1986), using the package CANOCO version 4.5

(TER BRAAK \& SMILAUER, 2002). The CCA method operates on abundances of species and data on environmental variables at sites, and extracts from the environmetal variables synthetic gradients (ordination axes) that maximize the niche separation among species (TER BRAAK $\&$ VERDONSCHOT, 1995). In preparation for direct gradient analysis of microhabitat use, data were arranged in two matrices: samples by species, and samples by environmental variables. From the original samples by species matrix rarer species (less than 3\% of occurrence) were eliminated. Subsequently, some abiotic environmental variables were eliminated, because the correlation with some biotic variables was too high (more than 0.50). Prior to the CCA, the statistical significance of the effect of each variable was tested by a Monte Carlo permutation test (TER BRAAK \& VERDONSCHOT, 1995). Finally, the two reduced matrices were subsequently subjected to CCA.

For spatial data analysis we used QuantumGIS 2.18.11. tools. All heterobranchs were photographed and fixed in $90 \%$ alcohol solution, catalogued and deposited in the collection of the Institute of Marine Biology, University of Montenegro.

\section{RESULTS}

Thirtyeight heterobranch species were recorded during sampling surveys in the BKB in the summer 2017 (Table 1). Records for 7 new heterobranch species were provided by field surveys in 2017, while records for 3 new species were provided by analysing underwater photographs from previous periods (Table 2). Details concerning only those species never recorded before in the studied area are provided below.

\section{Order ANASPIDEA \\ Family Aplysiidae}

\section{Aplysia parvula Mørch, 1863}

The small anaspidean was reported for the first time for the Montenegrin heterobranch fauna in July 2017 on rocky bottom with turf. $A$. parvula specimens were found at the entrance of BKB (cape Debeli and island Mamula) and in open waters as well (Dobra Luka). It was observed in shallow marine waters, aproximatelly at $5 \mathrm{~m}$ depth. This species has a cosmopolitan distribution. According to the new knowledge recently published by GOLESTANI et al. (2019) this species should be attributed to the taxon Aplysia punctata.

\section{Aplysia punctata (Cuvier, 1803)}

It was found on several locations in the BKB (Sv. Stasija, Orahovac and Opatovo), mostly in seagrass meadows. A. punctata was abundant during late summer months in 2017.

\section{Order NUDIBRANCHIA Family Discodorididae}

\section{Paradoris indecora (Bergh, 1881)}

This dorid nudibranch was recorded near Mamula island in July 2017. The only specimen 
Table 1. Checklist of the heterobranch species found so far in the Montenegro and in present study for the Boka Kotorska

Bay (+ already published, NR-new record)

\begin{tabular}{|c|c|c|c|c|}
\hline & SPECIES & ORDER & $\begin{array}{l}\text { PREVIOUS DATA } \\
\text { (MONTENEGRO) }\end{array}$ & $\begin{array}{c}\text { PRESENT } \\
\text { STUDY } \\
\text { BOKA } \\
\text { KOTORSKA } \\
\text { BAY }\end{array}$ \\
\hline 1 & Acteon tornatilis (Linnaeus, 1758) & INCERTAE SEDIS & + & \\
\hline 2 & Ringicula auriculata (Ménard de la Groye, 1811) & INCERTAE SEDIS & + & \\
\hline 3 & Ringicula conformis Monterosato, 1877 & INCERTAE SEDIS & + & \\
\hline 4 & Ringicula gianninii F. Nordsieck, 1974 & INCERTAE SEDIS & + & \\
\hline 5 & Rissoella diaphana (Alder, 1848) & INCERTAE SEDIS & + & \\
\hline 6 & Bulla striata (Bruguière, 1792) & CEPHALASPIDA & + & \\
\hline 7 & Haminoea hydatis (Linnaeus, 1758) & CEPHALASPIDA & + & \\
\hline 8 & Haminoea navicula (da Costa, 1778) & CEPHALASPIDA & + & \\
\hline 9 & Weinkauffia turgidula (Forbes, 1844) & CEPHALASPIDA & + & \\
\hline 10 & Philine quadripartita Ascanius, 1772 & CEPHALASPIDA & + & \\
\hline 11 & Hermania scabra (O. F. Müller, 1784) & CEPHALASPIDA & + & \\
\hline 12 & Cylichna cylindracea (Pennant, 1777) & CEPHALASPIDA & + & \\
\hline 13 & Volvulella acuminata (Bruguière, 1792) & CEPHALASPIDA & + & \\
\hline 14 & Heliconoides inflatus (d'Orbigny, 1835) & THECOSOMATA & + & \\
\hline 15 & Limacina bulimoides (d'Orbigny, 1835) & THECOSOMATA & + & \\
\hline 16 & Limacina trochiformis (d'Orbigny, 1835) & THECOSOMATA & + & \\
\hline 17 & Atlanta helicinoidea J.E.Gray, 1850 & THECOSOMATA & + & \\
\hline 18 & Creseis acicula (Rang, 1828) & THECOSOMATA & + & \\
\hline 19 & Creseis virgula (Rang, 1828) & THECOSOMATA & + & \\
\hline 20 & Cymbulia peronii Blainville, 1818 & THECOSOMATA & + & \\
\hline 21 & Pneumodermopsis canephora Pruvot-Fol, 1924 & THECOSOMATA & + & \\
\hline 22 & Elysia timida Risso, 1818 & SACCOGLOSSA & + & + \\
\hline 23 & Elysia viridis Montagu, 1804 & SACCOGLOSSA & & NR \\
\hline 24 & Thuridilla hopei (Vérany, 1853) & SACCOGLOSSA & + & + \\
\hline 25 & Bosellia mimetica Trinchese, 1891 & SACCOGLOSSA & + & + \\
\hline 26 & Umbraculum umbraculum Lightfoot, 1786 & NOTASPIDEA & + & \\
\hline 27 & Tylodina perversa $($ Gmelin, 1791) & NOTASPIDEA & + & + \\
\hline 28 & Akera bullata O. F. Müller, 1776 & ANASPIDA & + & + \\
\hline 29 & Aplysia dactyomela Rang, 1828 & ANASPIDA & + & + \\
\hline 30 & Aplysia fasciata Poiret, 1789 & ANASPIDA & + & + \\
\hline 31 & Aplysia parvula Mörch, 1863 & ANASPIDA & & NR \\
\hline 32 & Aplysia punctata (Cuvier, 1803) & ANASPIDA & & NR \\
\hline 33 & Bursatella leachii Blainville, 1817 & ANASPIDA & + & + \\
\hline 34 & Doris bertheloti (d'Orbigny, 1839) & NUDIBRANCHIA & + & \\
\hline 35 & Atagema rugosa Pruvot-Fol, 1951 & NUDIBRANCHIA & + & \\
\hline 36 & Baptodoris cinnabarina Bergh, 1884 & NUDIBRANCHIA & + & \\
\hline 37 & Geitodoris portmanni (Schmekel, 1972) & NUDIBRANCHIA & + & \\
\hline
\end{tabular}




\begin{tabular}{|c|c|c|c|c|}
\hline 38 & Paradoris indecora (Bergh, 1881) & NUDIBRANCHIA & & NR \\
\hline 39 & Peltodoris atromaculata Bergh, 1880 & NUDIBRANCHIA & + & + \\
\hline 40 & Platydoris argo (Linnaeus, 1767) & NUDIBRANCHIA & + & + \\
\hline 41 & Felimare orsinii (Vérany, 1846) & NUDIBRANCHIA & + & \\
\hline 42 & Felimare picta (Philippi, 1836) & NUDIBRANCHIA & + & + \\
\hline 43 & Felimare tricolor (Cantraine, 1835) & NUDIBRANCHIA & + & + \\
\hline 44 & Felimare fontandraui (Pruvot-Fol, 1951) & NUDIBRANCHIA & & NR \\
\hline 45 & Felimida krohni (Vérany, 1846) & NUDIBRANCHIA & + & \\
\hline 46 & Felimida luteorosea (Rapp, 1827) & NUDIBRANCHIA & + & + \\
\hline 47 & Phyllidia flava Aradas, 1847 & NUDIBRANCHIA & + & + \\
\hline 48 & Doriopsilla areolata Bergh, 1880 & NUDIBRANCHIA & + & + \\
\hline 49 & Diaphorodoris papillata Portmann \& Sandmeier, 1960 & NUDIBRANCHIA & + & \\
\hline 50 & Melibe viridis Kelaart, 1858 & NUDIBRANCHIA & + & + \\
\hline 51 & Tethys fimbria Linnaeus, 1767 & NUDIBRANCHIA & + & + \\
\hline 52 & Antiopella cristatas Delle Chiaje, 1841 & NUDIBRANCHIA & + & + \\
\hline 53 & Cratena peregrina (Gmelin, 1791) & NUDIBRANCHIA & + & + \\
\hline 54 & Dicata odhneri Schmekel, 1967 & NUDIBRANCHIA & + & + \\
\hline 55 & Dondice banyulensis Portmann \& Sandmeier, 1960 & NUDIBRANCHIA & + & + \\
\hline 56 & Facelina fusca Schmekel, 1966 & NUDIBRANCHIA & + & + \\
\hline 57 & Facelina quatrefagesi (Vayssière, 1888) & NUDIBRANCHIA & & NR \\
\hline 58 & Favorinus branchialis (Rathke, 1806) & NUDIBRANCHIA & & NR \\
\hline 59 & Flabellina affinis (Gmelin, 1791) & NUDIBRANCHIA & + & + \\
\hline 60 & Luisella babai (Schmekel, 1972) & NUDIBRANCHIA & + & + \\
\hline 61 & $\begin{array}{l}\text { Paraflabellina ischitana (Hirano \& T. E. Thompson, } \\
\text { 1990) }\end{array}$ & NUDIBRANCHIA & & NR \\
\hline 62 & Edmundsella pedata (Montagu, 1816) & NUDIBRANCHIA & + & + \\
\hline 63 & Flabellinopsis iodinea (J. G. Cooper, 1863) & NUDIBRANCHIA & + & \\
\hline 64 & Rubramoena amoena (Alder \& Hancock, 1845) & NUDIBRANCHIA & & NR \\
\hline 65 & Trinchesia genovae (O’Donoghue, 1926) & NUDIBRANCHIA & & NR \\
\hline 66 & Tritonia nilsodhneri Marcus Ev., 1983 & NUDIBRANCHIA & + & + \\
\hline 67 & Thecacera pennigera (Montagu, 1813) & NUDIBRANCHIA & + & + \\
\hline 68 & Marionia blainvillea (Risso, 1818) & NUDIBRANCHIA & + & + \\
\hline 69 & Discodoris rosi Ortea, 1979 & NUDIBRANCHIA & + & \\
\hline 70 & Polycera elegans (Bergh, 1894) & NUDIBRANCHIA & + & \\
\hline \multirow[t]{2}{*}{71} & Calmella cavolini (Bergh, 1894) & NUDIBRANCHIA & + & \\
\hline & TOTAL: & & & 38 \\
\hline
\end{tabular}

was found on the rocky bottom, at approximately $7 \mathrm{~m}$ depth.

\section{Family Chromodorididae}

4. Felimare fontandraui (Pruvot-Fol, 1951)

The only specimen was found in Dražin vrt in August 2013. It was photographed in »vrulja habitat, on rocky bottom with turf and identified following FURFARO et al. (2016b).

\section{Family Facelinidae}

5. Facelina quatrefagesi (Vayssière, 1888)

It was firstly recorded in "vrulja" habitat, on the coral Leptogorgia sarmentosa in Strp, in August 2015. After this, it was observed also in November 2016, in Porto Montenegro marina on artificial hard bottom. Identification was done following Furfaro et al. (2016a). 
Table 2: Heterobranch molluscs recorded in the Boka Kotorska Bay as new records - NR. (Photo by: Milica Jovanović - 1, 3, 6, 8, 9, 10 and Vesna Mačić - 2, 4, 5, 7).

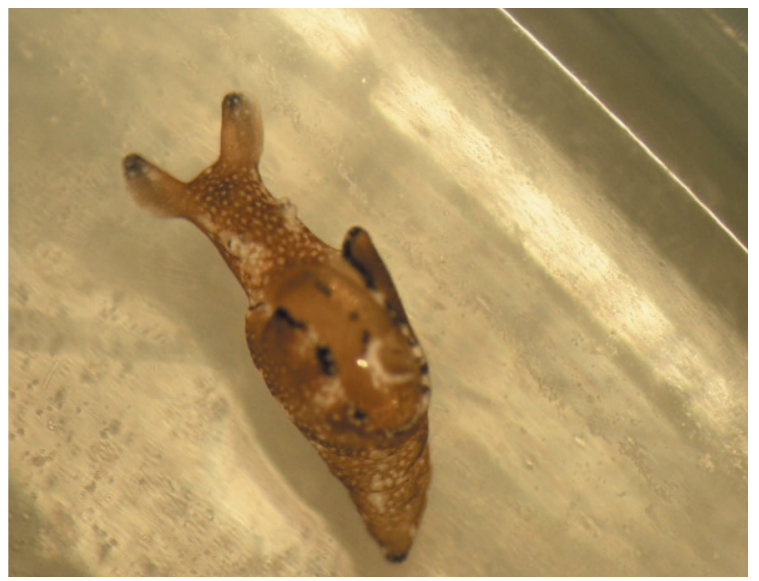

1) Aplysia parvula

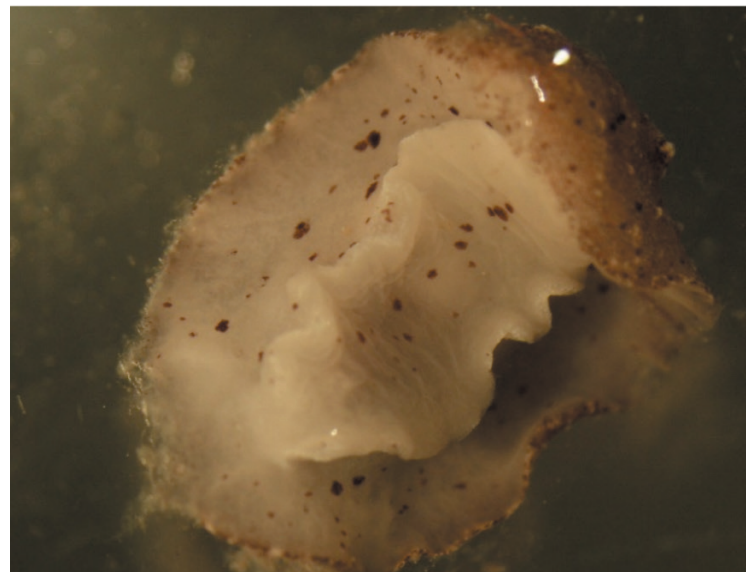

3) Paradoris indecora

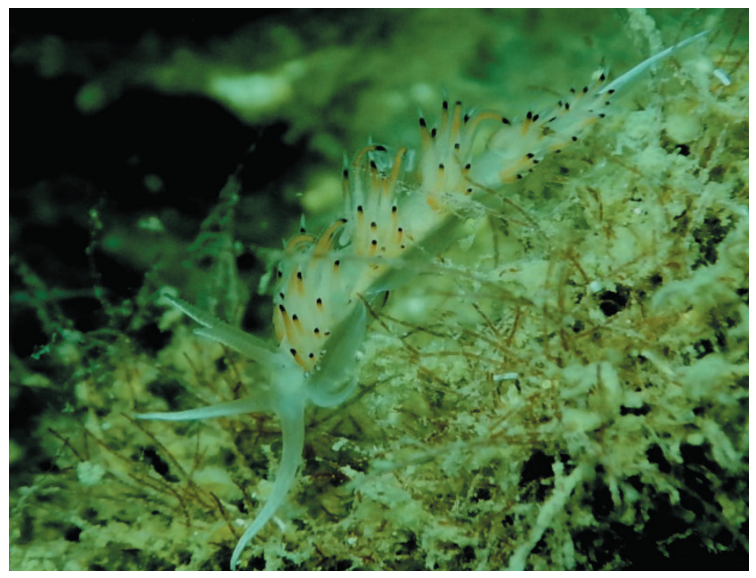

5) Facelina quatrefagesi

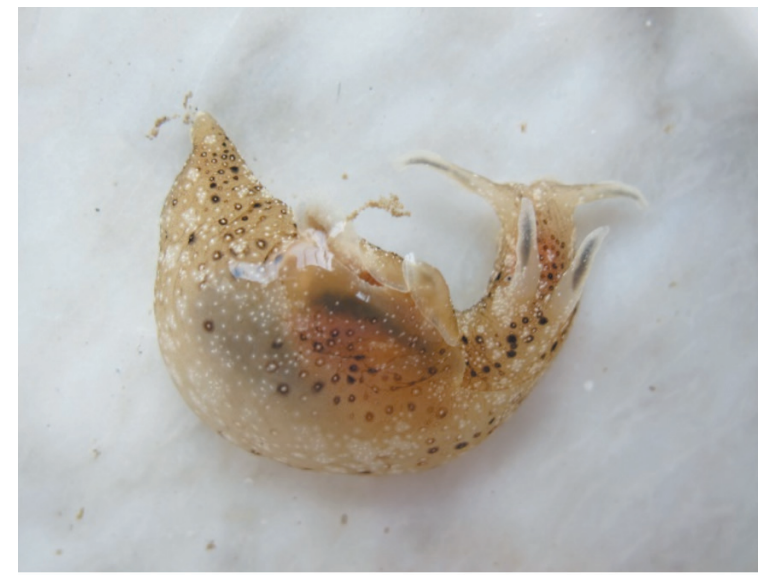

2) Aplysia punctata

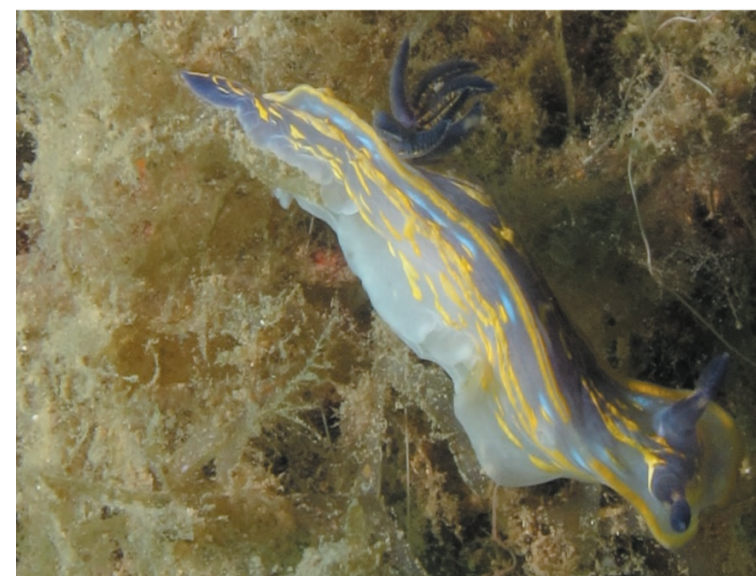

4) Felimare fontandraui

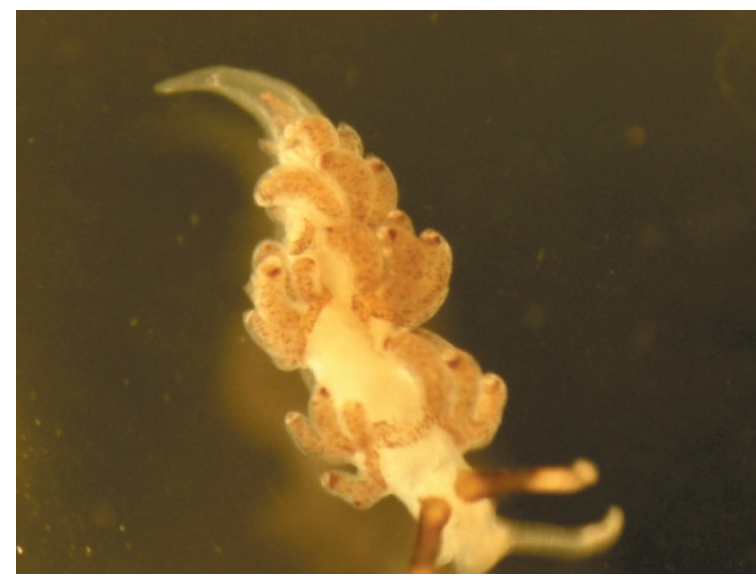

6) Favorinus branchialis 


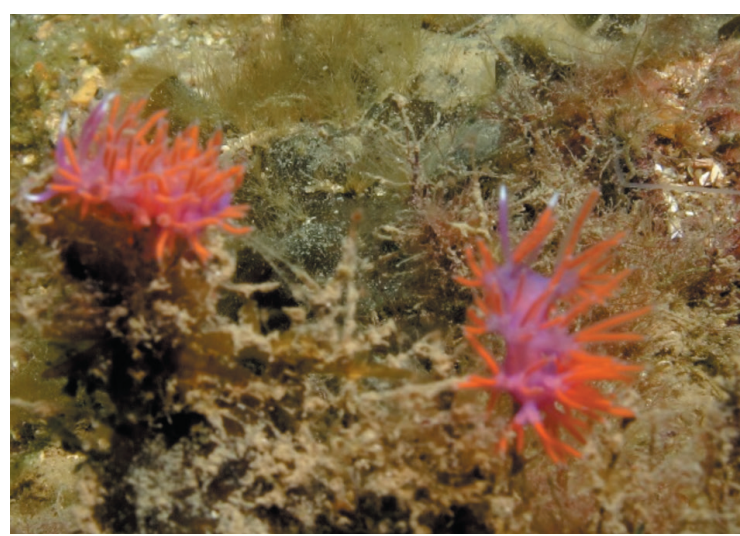

7) Flabellina ischitana

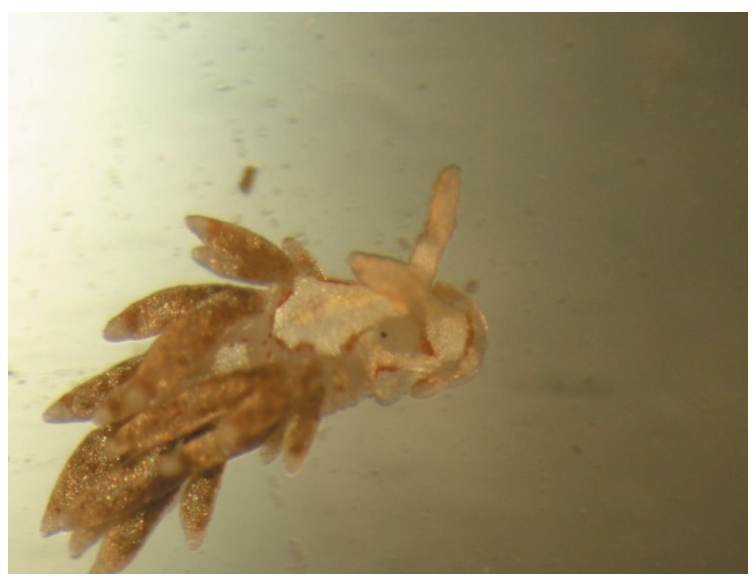

9) Trinchesia genovae

\section{Favorinus branchialis (Rathke, 1806)}

Two specimens were found in July 2017 on turf at $9 \mathrm{~m}$ depth, near the island Sv. Nedelja. In the same month, one specimen was found in the locality Markov Rt on rocky bottom with turf, at $7 \mathrm{~m}$ depth.

\section{Flabellina ischitana Hirano \& Thompson,} 1990

The presence of this species in the study area was confirmed by the analysis of underwater photographs from Verige and Dražin Vrt in April 2013 and Porto Montenegro marina in April 2014. Additionaly, it was recorded at Dražin Vrt in February, 2017. It was recorded on »vrulja« habitat as well as on detritic and rocky bottom.

\section{Family Trinchesiidae} 1845)

8. Rubramoena amoena (Alder \& Hancock,

Two specimens were found in Stoliv, on

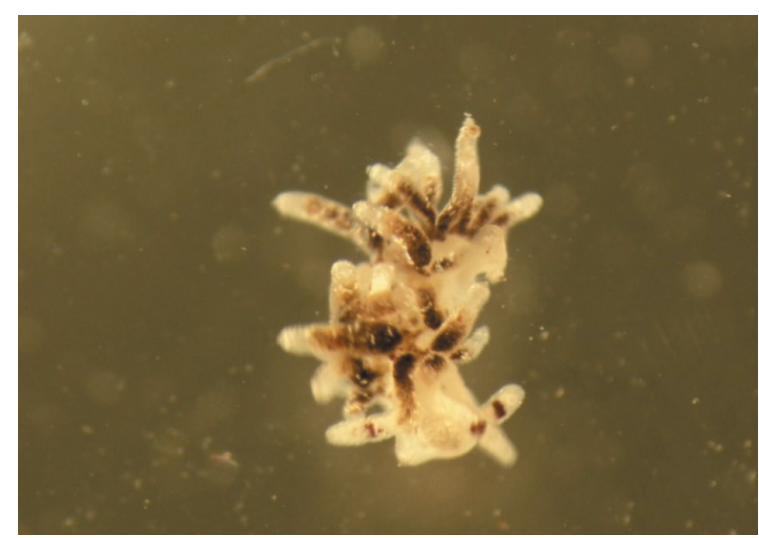

8) Rubramoena amoena

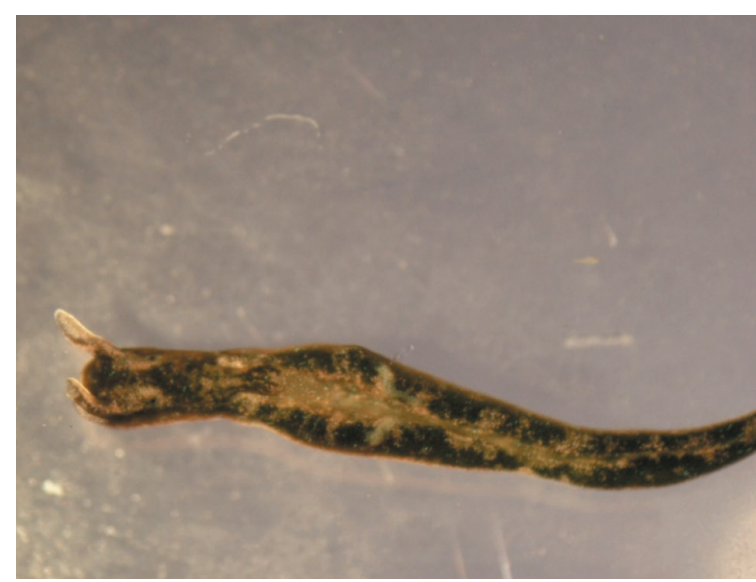

10) Elysia viridis

Cystoseira foeniculacea f. latiramosa (Ercegovic) A.Gómez Garreta, M.C.Barceló, M.A.Ribera \& J.R.Lluch, 2001, at 7-8 $\mathrm{m}$ depth, in July and September 2017.

9. Trinchesia genovae (O’Donoghue, 1926)

Two specimens were found in the location Markov Rt, at approximately $8 \mathrm{~m}$ depth, in July 2017.

\section{Order SACOGLOSSA}

\section{Family Plakobranchidae}

10. Elysia viridis (Montagu, 1804)

This sacoglossan was abundant during warmer periods in 2017. It was found on thalli of numerous algae, such as Ulva, Cystoseira, Flabellia and other species.

Summarizing all findings, 62 heterobranchs species has been recorded to date in BKB area. Almost half of the recorded species were 
observed in more than one macrohabitat. The rocky substrata was the richest in species, with an amount of 23 taxa (almost 44\%) (Fig. 2). Seagrass meadows and sandy-muddy bottom appeared to be poorly inhabited macrohabitats by seaslugs, even less than artificial hard bottom (Fig. 2). Only 14 heterobranchs were observed on sandy bottom, but their abundance was rather high (Fig. 3). On the sandy bottom the highest proportion $(59.2 \%)$ of detected specimens (516) was recorded. Among species inhabiting this macrohabitat type, the greatest number of individuals belongs to cephalaspideans, Ringicula conformis Monterosato, 1877 and Acteon tornatilis (Linnaeus, 1758). Moreover, $95.7 \%$ of A. tornatilis specimens were found in this macrohabitat, while $R$. conformis individuals found on sandy bottom represent $89.2 \%$ of all observations for this particular cephalaspidean.

Considering 42 surveyed microhabitats, all heterobranch species are considered as infrequent (appearing in 1-25\% of microhabitats). Only few species occured in more than $10 \%$ of all microhabitats, and the most frequent was Felimare picta (SCHULTZ IN PHILIPPI, 1836) presents in $23.8 \%$ of all microhabitats.

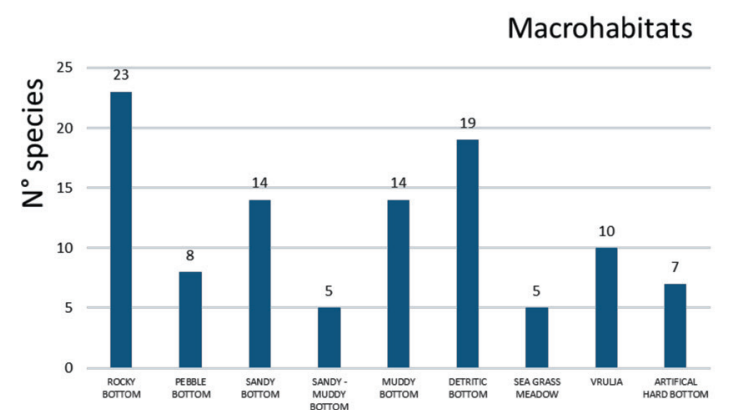

Fig. 2. Number of recorded heterobranch species per different macrohabitats in the $B K B$

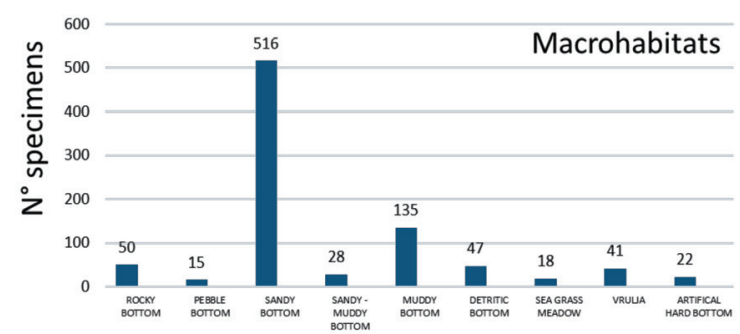

Fig. 3. Number of recorded heterobranch specimens per different macrohabitats in the $B K B$

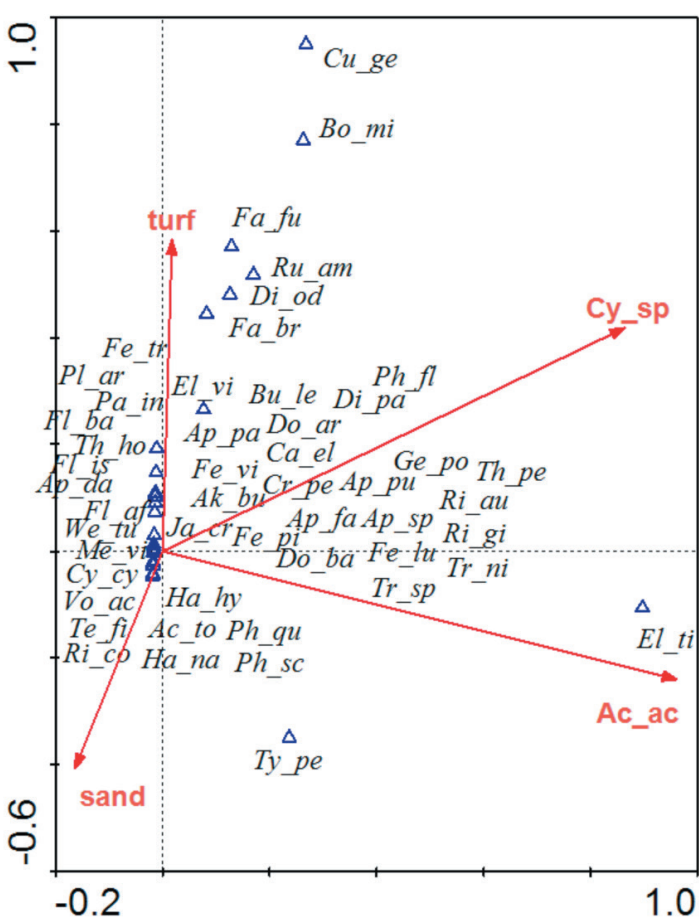

Fig. 4. CCA ordination diagram showing the main pattern of variation in heterobranch assemblages, accounted by four microhabitat variables: turf, sand, Acetabularia acetabularia (Ac_ac) and Cystoseira species (Cy_sp), for species recorded in the period from 1967 until 2017

Legend: Ac_to = Acteon tornatilis, $A k \_b u=$ Akera bullata, Ap_da = Aplysia dactyomela, Ap_fa = Aplysia fasciata, Ap_pa = Aplysia parvula, Ap_pu = Aplysia punctata, Ap_sp = Aplysia sp., Bo_mi $=$ Bosellia mimetica, Bu_le $=$ Bursatella leachii, Ca_el $=$ Facelina quatrefagesi, $\bar{C} r$ pe = Cratena peregrina, $C u \_g e=$ Trinchesia genovae, $C y \_c y$ = Cylichna cylindracea, Di pa = Diaphorodoris papillata, Di_od = Dicata odhneri, Do_ba $=$ Dondice banyulensis, Do_ar = Doriopsilla areolata, El_ti = Elysia timida, El_vi $=$ Elysia viridis, Fa_fu = Facelina fusca, Fa_br = Favorinus branchialis, $\mathrm{Fe} \_\mathrm{pi}=$ Felimare picta, $\mathrm{Fe} \_v i=$ Felimare fontandraui, $\mathrm{Fe} \_\mathrm{tr}=$ Felimare tricolor, $\mathrm{Fe} \_\mathrm{lu}=$ Felimida luteorosea, Fl_af $=$ Flabellina affinis, $F l \_b a=$ Flabellina babai, Fl_is = Flabellina ischitana, Fl_pe = Flabelina pedata, Ge po = Geitodoris portmanii, Ha_hy = Haminoea hydatis, Ha_na = Haminoea navicula, Ja_cr = Janolus cristatus, Me vi $=$ Melibe viridis, $\mathrm{Pa}$ in $=$ Paradoris indecora, $P e \_a t=P e l t o d o r i s$ atromaculata, $P h \_q u=$ Philine quadripartita, $P h \_s c=$ Hermania scabra, $P h \_f l=$ Phylida flava, Pl_ar = Platydoris argo, Ri_au = Ringicula auriculata, Ri_gi $=$ Ringicula gianini, Ri_co $=$ Ringicula conformis, $R u$ am = Rubroamoena amoena, $T e$ f $i=$ Tethys fimbria, Th_pe $=$ Thecacera penigera, Th_ho $=$ Thuridila hopei, $T r \_n i=$ Tritonia nilsodhneri, Tr_sp $=$ Tritonia $s p$., Ty_pe $=\overline{T y}$ lodina perversa, Vo_ac $=$ Volvulella acuminata, We_tu = Weinkauffia turgidula. 
The highest number of species in a single microhabitat was recorded for hard bottom with turf (18), much more than in any other microhabitat. Nine species were detected on muddy bottom, followed by sandy-muddy, detritus and a combination of sand and mud (all with 7 species).

The CCA diagram shows the main pattern of variation in heterobranch assemblages, accounted by the microhabitat variables (Fig. 4). Additionally, it represents the distribution of single species along each microhabitat variable. Statistically significant correlation $(p<0.05)$ was found between 52 heterobranch species and four environmental variables: turf, sand, Acetabularia acetabularia and Cystoseira spp. species. Even though the majority of the species are close to the centre of the diagram, and do not show any major preference for a particular variable, some main groups can be distinguished. The first group shows a preference for microhabitats with dominant turf, especially Facelina fusca Schmekel, 1966, Favorinus branchialis (Rathke, 1806), Dicata odhneri Schmekel, 1967 and Rubramoena amoena (Alder \& Hancock, 1845). Flabellinids were also observed grazing on turf (in many cases together with hydrozoans), as well as sacoglossans like Thuridilla hopei (Vérany, 1853) and Elysia viridis (Montagu, 1804). Bosellia mimetica Trichese, 1891 and Trinchesia genovae (O'Donoghue, 1926) are the species with the highest correlation with algae belonging to Cystoseira genus, while $E$. timida (Risso, 1818) specimens were found mostly on thalli of $A$. acetabularia. The highest preference for microhabitats dominated by sand was shown by cephalaspideans including $R$. conformis, Haminoea hydatis (Linnaeus, 1758), H. navicula (da Costa, 1778), A. tornatilis, Hermania scabra (O.F. Müller, 1784) and Philine quadripartita Ascanius, 1772.

\section{DISCUSSION}

In the present work are reported data for 38 heterobranch species recorded in the summer 2017 in the BKB, and 10 species previously not reported for Montenegrin waters. Records of Facelina quatrofagesi, Felimare fontandraui and Flabellina ischitana were identified by the analysis of underwater photographs from previous periods, while Aplysia parvula, A. punctata, Elysia viridis, Paradoris indecora, Favorinus branchialis, Rubramoena amoena and Trinchesia genovae were recorded during the fieldwork in 2017. For other species already known for Montenegrin waters, data on additional localities were provided.

Summarizing all available data, a total of 62 heterobranch species was up to date recorded for BKB and 71 for Montenegro. Majority of the species belongs to Nudibranchia. Mediterranean Sea hosts around 363 species of Opisthobranchia (TRAINITO \& DONEDDU, 2014), but increased research effort resulted in an increasing trend of the number of registered species. The obtained data for the Montenegrin part of the Adriatic Sea suggest that only a small portion (19\%) of Mediterranean heterobranchs inhabits this area. However, the number of species of heterobranch recovered for BKB increases at every sampling survey and it is far from being considered as complete, conseguently, more intensive studies are needed in the future that could result in many new records and significantly improve the present checklist.

Interestingly some of the species recovered for the BKB site (Dicata odhneri, Marionia blainvillea and Geitodoris portmanni) are considered as rare in Mediterranean basin, highlighting the ecological value of the Montenegrin Adriatic waters (DESCO, 2009; LIPEJ et al., 2018). Between our findings and those from previous studies by STJEPČEVIĆ (1967) and STJEPČEVIĆ \& PARENZAN $(1980 ; 1982)$ there is a huge discrepancy. The possible reason has to be assessed to differences in methodological sampling since we have used mainly SCUBA diving technics compared to the dredging methods used by other authors and to the different macrohabitats explored, hard bottom in the present study and soft bottoms in previous expeditions. For examples, Cephalaspideans inhabit mainly sandy and muddy bottom, and it is quite difficult to observe them without a sampling with a dredge or a grab. Because of that, for comparisons with old stud- 
ies, new surveys should be performed using the same sampling methodology.

An important indirect result of this study is the investiogation and monitoring of nonindigenous species (NIS) that are confirmed to occure also in BKB area. In particular, four NIS are reported for the studied area: Bursatella leachii, Melibe viridis, Aplysia dactyomela and A. parvula. Apart from the latter species that was observed for the first time during our survey in 2017 near the entrance of BKB, all other NIS have been already reported from Montenegro. Since B. leachii and M. viridis were recorded with their spawning several times and they are considered as established alien species (MAČIĆ, 2013; MANDIĆ et al., 2016). Species $A$. dactylomela was previously recorded only twice in the Herceg Novi bay in autumn 2011 and winter 2012 (KLJAJIĆ \& MAČIĆ in THESSALOU-LEGAKI et al., 2012).

Further research focused on this group of molluscs needs to be carried out in order to deepen the knowledge about these organisms and their ecological features along the BKB coast.

\section{REFERENCES}

BADALAMENTI, F., J.A. GARCIA CHARTON, D. CEBRIÁN, V. MAČIĆ \& S. KAŠĆELAN. 2008. Development of Marine and Coastal Protected Areas (MPAs) in the Republic of Montenegro. Working draft: only internal use for RAC/SPA \& Montenegro official institutions, December 2008, 48 pp.

BELlAFIORE, D., A. GUARNIERI, F. GRILLI, P. PENNA, G. BORTOLUZZI, F. GIGLIO, \& N. PINARDI. 2011. Study of the hydrodynamical processes in the Boka Kotorska Bay with a finite element model. Dynamics of atmospheres and oceans, 52(1-2): 298-321.

COPP, G. H. \& P. JURAJDA. 1999. Size-structured diel use of river banks by fish. Aquatic Sciences, 61: $75-91$.

DESCO, K. 2009. The ecology of opisthobranch molluscs (Mollusca: Gastropoda) of the Gulf of Trieste (northern Adriatic). Joint study, Università degli studi di Trieste, University of Primorska, Koper, 106 pp.

FURFARO G., P. MARIOTTINI, M.V. MODICA, E. TRAINITO, M. DONEDDU \& M. OLIVERIO. 2016a. Sympatric sibling species: the case of Caloria elegans and Facelina quatrefagesi (Gastropoda: Nudibranchia). Scientia Marina, 80 (4), 511-520.

FURFARO G., M.V. MODICA \& M. OLIVERIO, P. MARIOTTINI. 2016b. A DNA-barcoding approach to the phenotypic diversity of Mediterranean species of Felimare Ev. Marcus \& Er. Marcus, 1967 (Mollusca: Gastropoda), with a preliminary phylogenetic analysis. Italian Journal of Zoology, 83 (2), 195-207.

FURFARO G., D. SALVI, E. MANCINI \& P. MARIOTTINI 2018. A multilocus view on Mediterranean aeolid nudibranchs (Mollusca): systematics and cryptic diversity of Flabellinidae and Piseinotecidae. Molecular Phylogenetic and Evolution, 118, 13-22

GOLESTANI, H., F. CROCETTA, V. PADULA, Y, CAMACHO-GARCÍA, J. LANGENECK, D. POURSANIDIS, M. POLA, M BAKI YOKEŞ, L. CERVERA, DAE-WUI JUNG, T. M GOSLINER, J. F. ARAYA, Y. HOOKER, M. SCHRÖDL, Á. VALDÉS, 2019. The little Aplysia coming of age: from one species to a complex of species complexes in Aplysia parvula (Mollusca: Gastropoda: Heterobranchia), Zoological Journal of the Linnean Society, Volume 187, Issue 2, October 2019, Pages 279-330, https://doi.org/10.1093/ zoolinnean/zlz028

KLJAJIĆ, Z. \& V. MAČIĆ. 2012. The alien sea hare Aplysia dactylomela Rang, 1828 (Opistobranchia) in the Boka Kotorska Bay (Montenegro, Adriatic Sea) in M.Thessalou, Ö Aydogan, P. Bekas, G. Bilge, Y. Ö. Boyac, E. Brunelli, V. Circosta, F. Crocetta, F. Durucan, M. Erdem, A. Ergolavou, H. Filiz, F. Fois, E. Gouva, K. Kapiris, S. Katsanevakis, E. Konstantinidis, G. Konstantinou, D. Koutsogiannopoulos, S. Lamon, R. Mazzette, D. Meloni, A. Mureddu, I. Paschos, C. Perdikaris, F. Piras, D. Poursanidis, A.A. Ramos- 
Esplá, A. Rosso, P. Sordino, E. Sperone, A. Sterioti, E. Taşkin, F. Toscano, S. Tripepi, L. Tsiakkiros and A. Zenetos: New Mediterranean Biodiversity Records (December 2012) COLLECTIVE ARTICLE, Mediterranean Marine Science, 13/2: 312-327.

LEPETIĆ, V. 1965. Composition and dynamics of ichthyobenthos and edible invertebrata in Bay of Boka Kotorska and possibilities of their exploitation, Studia Marina, 1, p. 164.

LIPEJ, L., D. TRKOV \& B. MAVRIČ. 2018. Polži zaškrgarji Slovenskega morja, Nacionalni inštitut za biologijo, Morska biološka postaja, Piran.

MAČIĆ, V. 2013. Contribution to the knowledge of Bursatella leachii (de Blainville, 1817) distribution and reproduction in the Boka Kotorska Bay (Montenegro). Studia Marina 26(1): 119-128.)

MANDIĆ, M., V. MAČIĆ \& O. MARKOVIĆ. 2016. Spawning of the alien nudibranch Melibe viridis (Kelaart, 1858) in South Adriatic Sea (Montenegro). Fresenius Environmental Bulletin: 25 (11-2016): 4566-4568.

PETOVIĆ, S., S. GVOZDENOVIĆ \& Z. IKICA. 2017. An Annoted Checklist of the Marine Molluscs of the South Adriatic Sea (Montenegro) and a Comparison with Those of Neighbouring Areas. Turkish Journal of Fisheries and Aquatic Sciences, DOI: 10.4194/1303-2712v17_5_08.

PETOVIĆ, S. 2018. Additions to the checklist of the malacofauna of the Boka Kotorska Bay (south-east Adriatic Sea). Studia Marina, 31 (1): 23-36.

PETOVIĆ, S. \& L. LIPEJ. 2017. First record of the sea slug Thecacera pennigera (Montagu, 1815), (Nudibranchia, Polyceridae) in the Adriatic Sea: In V. GEROVASILEIOU, E.H.KH. AKEL, O. AKYOL, G. ALONGI, F. AZEVEDO, N. BABALI, R. BAKIU, M. BARICHE, A. BENNOUI, L. CASTRIOTA, C.C. CHINTIROGLOU, F. CROCETTA, A. DEIDUN, S. GALINOU-MITSOUDI, T. GIOVOS, M. GÖKOĞLU, A. GOLEMAJ, L. HADJIOANNOU, J. HARTINGEROVA, G. INSACCO, S. KATSANEVAKIS, P. KLEITOU, J. KORUN, M. MALEGUE, N. MICHAILIDIS, A. MOUZAI TIFOURA, P. OVALIS, S. PIRAINO, S.I. RIZKALLA, M.
ROUSOU, I. SAVVA, H. ŞEN, A. SPINELLI, K.G. VOUGIOUKALOU, E. XHARAHI, B. ZAVA, A. ZENETOS (July 2017): New Mediterranean Biodiversity Records, collective article DOI: http://dx.doi.org/10.12681/mms.2068.

QGIS DEVELOPMENT TEAM. 2017. QGIS Geographic Information System 2.18.11. Open Source Geospatial Foundation Project. http:// qgis.osgeo.org

RAC/SPA. 2013. Ecological quantitative description of Boka Kotorska (Kotor) bay marine area. By Golder associates. (Editors). RAC/ SPA, Tunis 82 pp + Appendices.

STJEPČEVIĆ, J. 1967. Macro-Mollusca of Boka Kotorska Bay. Studia Marina, 2: 1-64.

STJEPČEVIĆ, J. \& P. PARENZAN. 1980. Il Golfo delle Boche di Cataro-condizioni generalli e biocenosi bentoniche con carta ecologica delle sue due baie interne: di Kotor (Cattaro) e Risan (Risano). Studia Marina, 9-10: 3-148.

STJEPČEVIĆ, J. \& P. PARENZAN. 1982. Pregled bentoskih populacija Mollusca (Amphineura, Scaphopoda, Gastropoda, Bivalvia) unutrašnjeg dijela Bokokotorskog zaliva. Studia Marina, 11-12: 3-27.

TER, BRAAK, C. J. F. 1986. Canonical correspondence analysis: a new eigenvector technique for multivariate direct gradient analysis. Ecology 67, 1176-1179.

TER, BRAAK, C. J. F. \& P.F.M. VERDONSCHOT. 1995. Canonical correspondence analysis and related multivariate methods in aquatic ecology. Aquatic Sciences 57 (3), 255-289.

TER BRAAK, C. J. F., \& P. SMILAUER. 2002. CANOCO Reference Manual and CanoDraw for Windows User's Guide: Software for Canonical Community Ordination (version 4.5). (Microcomputer Power). Ithaca NY, USA: www.canoco.com.

TRAINITO, E. \& M. DONEDDU. 2014. Nudibranchi del Mediterraneo. 2a Edizione, riveduta e ampliata. Il Castello, 190 pp.

UNEP. 1998. Draft classification of marine habitat types for the Mediterranean region. Mediterranean action plan. Meeting of experts on marine habitat types in the Mediterranean region. SPA/RAC, 149/3: Annex I and II. 
ZENETOS, A., V. MAČIĆ, A. JAKLIN, L. LIPEJ, D. POURSANIDIS, R. CATTANEO-VIETTI, S. BEQIRAJ, F. BETTI, D. POLONIATO, L. KASHTA, S. KATSANEVAKIS \& F. CROCETTA. 2016. Adriatic 'opisthobranchs' (Gastropoda, Hetero- branchia): shedding light on biodiversity issues. Marine Ecology, 37 (6): 1239-1255.

WORLD REGISTER OF MARINE SPECIES. 2018. (available at: http://www.marinespecies.org/ 12. 12.2018).

Received: 22 July 2019

Accepted: 19 September 2019

\title{
Pregled puževa golaća u Bokokotorskom zaljevu, Crna Gora
}

\author{
Milica JOVANOVIĆ*, Vesna MAČIĆ, Domen TRKOV, \\ Martina ORLANDO-BONACA i Lovrenc LIPEJ
}

*Kontakte-pošta:milicaj@ucg.ac.me

\section{SAŽETAK}

Fauna puževa golaća (Heterobranchia) u Crnoj Gori je do sada slabo istražena. Cilj ovog rada je bio unaprijediti saznanja o ovim morskim organizmima u zalivu Boka Kotorska, specifičnom, nalik fjordu zalivu južnog Jadrana. Novi nalazi za sedam vrsta heterobranchia su pronađeni tijekom naših terenskih istraživanja u 2017. godini, dok su podaci za tri nova nalaza dobijeni analizom podvodnih fotografija iz prethodnih razdoblja.

Ažurirana lista sumira saznanja o raznolikosti puževa golaća u Bokokotorskom zalijevu od najstarijeg zapisa iz 1967.g. do danas, a obuhvaća ukupno 62 vrste.

Ključne riječi: puževi golaći; Boka Kotorska; Crna Gora 